\title{
POTENTIAL APPLICATION OF BIOCHAR DEPENDS MAINLY ON ITS PROFITS FOR FARMERS: CASE STUDY IN SLOVAKIA
}

\author{
VLADIMÍR ŠIMANSKÝ*, ELENA AYDIN, DUŠAN IGAZ, JÁN HORÁK
}

Slovak University of Agriculture in Nitra, Slovak Republic

ŠIMANSKÝ, V. - AYDIN, E. - IGAZ, D. - HORÁK, J.: Potential application of biochar depends mainly on its profits for farmers: case study in Slovakia. Agriculture (Pol'nohospodárstvo), vol. 66, no. 4, pp. 171-176.

\begin{abstract}
Current biochar application in the global agronomic practice focuses firstly on economic profits. In this paper, we would like to draw attention to our results and experience from the economic assessment of the agronomic effect of applied biochar through the generated crop yields. The results come from a field experiment (locality Dolná Malanta, Slovakia, silt loam Haplic Luvisol - the most intensively used soil in the Slovak Republic for agricultural purposes), where a biochar experiment was established in 2014. Based on our data, it is evident that both the application of biochar and its application in combination with $\mathrm{N}$-fertilisation in field conditions at current realization prices of commodities in individual years and high input costs are still unprofitable. However, we emphasize that from an economic point of view of the standard agronomic practice.
\end{abstract}

Key words: farmers; biochar; economic profit

Biochar is the solid product of pyrolysis - thermal degradation of organic material in the absence of air - and one of the three products (bio-oil, syngas, biochar). Biochar is the name given to charcoal products intended for use in the agronomic and environmental applications. There has been a huge interest "boom" in the scientific community in the last ten years related to biochar application. Inspiration was taken from past soil management and biochar has been studied under controlled laboratory and field conditions. A number of scientific reviews (Jeffery et al. 2011; Barrow 2012; Lone et al. 2015; Tammeorg et al. 2017; El-Naggar et al. 2019; Han et al. 2020; Horák et al. 2020b) and significant book publications sharing the observations of European (Shackley et al. 2016), but also world (Verheijen et al. 2009; Lehmann et al. 2015; Rakshit et al. 2019) biochar experiments have been written. The individual studies mainly focused on the effects of biochar or its combination with other fertilisers (organic, mineral) on soil properties, including soil chemistry, physical state and soil biological properties, sequestration of $\mathrm{C}$ in the soil as a significant mitigation mechanism eliminating the increase of $\mathrm{CO}_{2}$ concentration in the atmosphere. The impact of biochar on crop yields is central to its application in agriculture.

doc. Ing. Vladimír Šimanský, PhD. (* Corresponding author), Department of Soil Science, FAFR - SUA Nitra, 94976 Nitra, Tr. A. Hlinku 2, Slovak Republic. E-mail: Vladimir.Simansky@uniag.sk

Ing. Elena Aydın, PhD., Department of Biometeorology and Hydrology, HLEF - SUA Nitra, 94976 Nitra, Hospodárska 7, Slovak Republic. E-mail: elena.aydin@uniag.sk

doc. Ing. Ján Horák, PhD., Department of Biometeorology and Hydrology, HLEF - SUA Nitra, 94976 Nitra, Hospodárska 7 , Slovak Republic. E-mail: jan.horak@uniag.sk

prof. Ing. Dušan Igaz, PhD., Department of Biometeorology and Hydrology, HLEF - SUA Nitra, 94976 Nitra, Hospodárska 7 , Slovak Republic. E-mail: dusan.igaz@uniag.sk 
The conclusions of many studies identified positive as well as negative aspects of biochar application. However, the positive effect, especially on the soil properties, was dominant. In most cases, a positive environmental effect on greenhouse gas emissions reduction from soil to atmosphere was observed as well. Considering the information available so far, it is evident that the results differ depending on the soil-climatic conditions, but also on the properties of the applied biochar or its combination with other fertilisers. Even though there are knowledge gaps in this area that need to be addressed, biochar has been identified by many scientific teams as a potential agronomic tool for sustainable land management (El-Naggar et al. 2019; Horák et al. 2020b; Rakshit et al. 2019; Rizhiya et al. 2019; Šimanský et al. 2019). In addition to the positive effects on the soil environment, its potential to solve ecology and waste management issues with the elimination of negative environmental impacts was also identified. The interest in biochar application is largely driven by its use as a climate change mitigation agent; lead-

$\mathrm{T}$ a $\mathrm{b} 1 \mathrm{e} 1$

Data for calculation of economy costs in the relevant year

\begin{tabular}{|c|c|c|c|c|c|c|c|c|}
\hline $\begin{array}{l}\text { Costs of } \\
1 \text { ton of } \\
\text { biochar } \\
\text { [EUR] }\end{array}$ & $\begin{array}{c}\text { Application rates } \\
\text { of biochar } \\
\text { [t/ha] }\end{array}$ & $\begin{array}{c}\text { Costs of biochar } \\
\text { application in the field } \\
\text { [EUR] }\end{array}$ & \multicolumn{6}{|c|}{$\begin{array}{c}\text { Commodity prices per } 1 \text { ton } \\
\text { [EUR] }\end{array}$} \\
\hline \multirow{2}{*}{795} & 10 & 16 & 2014 & 2015 & 2016 & 2017 & 2018 & 2019 \\
\hline & 20 & 32 & 180 & 135 & 150 & 140 & 175 & 135 \\
\hline
\end{tabular}

$\mathrm{T}$ a b 1 e 2

Profit from the sale of harvested crop on the market in the relevant year

\begin{tabular}{|c|c|c|c|c|c|c|c|c|}
\hline \multirow{2}{*}{ Treatments } & \multicolumn{6}{|c|}{ Individual years } & \multirow{2}{*}{$\begin{array}{l}\text { Cumulative } \\
\text { profit [EUR] }\end{array}$} & \multirow{2}{*}{$\begin{array}{c}\text { Relative } \\
\text { increase/ } \\
\text { decrease } \\
{[\%]}\end{array}$} \\
\hline & 2014 & 2015 & 2016 & 2017 & 2018 & 2019 & & \\
\hline B0N0 & 565 & 1,401 & 455 & 967 & 278 & 1,154 & 4,820 & 100 \\
\hline B10N0 & 805 & 1,432 & 410 & 790 & 242 & 1,239 & 4,918 & 102 \\
\hline $\mathrm{B} 20 \mathrm{~N} 0$ & 506 & 1,300 & 437 & 780 & 236 & 1,277 & 4,536 & 94 \\
\hline B0N1 & 580 & 879 & 552 & 934 & 308 & 1,478 & 4,731 & 100 \\
\hline B10N1 & 605 & 891 & 500 & 738 & 221 & 1,358 & 4,313 & 91 \\
\hline B20N1 & 567 & 928 & 602 & 1,080 & 277 & 1,381 & 4,835 & 102 \\
\hline $\mathrm{B} 0 \mathrm{~N} 2$ & 713 & 878 & 593 & 1,131 & 343 & 1,014 & 4,672 & 100 \\
\hline $\mathrm{B} 10 \mathrm{~N} 2$ & 842 & 1,013 & 588 & 900 & 284 & 1,284 & 4,911 & 105 \\
\hline B20N2 & 767 & 1,087 & 687 & 984 & 387 & 1,729 & 5,641 & 121 \\
\hline
\end{tabular}

Note 1: The field experiment had the following annual crop rotation: spring barley (Hordeum vulgare L.), corn (Zea mays L.), spring wheat (Triticum aestivum L.), corn, spring barley and corn in 2014, 2015, 2016, 2017, 2018 and 2019 , respectively.

Note 2: The field experiment was established with biochar application at different rates (B0, B10 and NB20 t/ha) in 2014 and different rates of $\mathrm{N}$ fertilisation (N0, N1 and N2 level of N fertilisation - 40 to $240 \mathrm{~kg} / \mathrm{kg} \mathrm{N}$ depending on the requirement of the cultivated crop) applied every year according to crop requirements. 
ing to a generation of an income stream linked to carbon credit payments and this fact can affect the economic viability of biochar in the near future.

Economic profit plays one of the most important roles in relation to decision making and the potential of biochar application by farmers in their current situation. This driver is similar anywhere in the world for everyday agronomic practice and for farmers themselves. In other words, the probability of choosing biochar as a soil amendment will most likely depend on the answer to the following question: Does the investment in purchase and biochar application pay off through the generated and subsequently sold crop yields? The farmer naturally expects that if he/she invests capital in the fertiliser or biochar or their combination, he/she will not only get the investments back but will also receive a reasonable profit from the yields sold on the market. From this point of view, efficiency of investment (at considerably high current prices of some certified biochar producers) that has a long-term return is questionable.

The Biochar Experiment in Slovakia from an Agronomical Point of View

In this context, we would like to draw the attention of the scientific community to our results and experience based on the economic assessment of the biochar application and its agronomic effect expressed by generated crop yields. Currently, information on the economics of biochar application and its agronomic effects is missing. Moreover, we present an evaluation of the continuous field experiment for a period of 6 years. To date, as the knowledge is based on short-term findings, it is forecasted that the return of investments in biochar through crop yields is a matter of many years. Our results come from a field experiment with biochar (locality Dolná Malanta, Slovakia, on silt loam Haplic Luvisol - the most intensively used soil type in the Slovak Republic for agricultural purposes) established in 2014. The certified biochar used in this case study was purchased from company Sonnenerde (Riedlingsdorf, Austria) in 2014. Biochar was made from paper fibre sludge and grain husks $(1: 1 \mathrm{w} / \mathrm{w})$ by pyrolysis at $550^{\circ} \mathrm{C}$ for 30 minutes in a Pyreg reactor (Pyreg GmbH, Dörth, Germany) and its price was very high at that time (Table 1). The most significant and already published findings related to the effect of biochar application on soil properties and crop yields from this experiment are summarized in the review paper of Horák et al. (2020b). Our findings confirmed that biochar produced by the pyrolysis of organic waste (not containing any harmful

T a b 1 e 3

Economic evaluation (in EUR) of crop yields in individual years after biochar application

\begin{tabular}{|c|c|c|c|c|c|c|}
\hline Treatments & 2014 & 2015 & 2016 & 2017 & 2018 & 2019 \\
\hline B0N0 & 0 & 0 & 0 & 0 & 0 & 0 \\
\hline B10N0 & $-7,726$ & $-7,695$ & $-7,740$ & $-7,917$ & $-7,953$ & $-7,868$ \\
\hline B20N0 & $-15,991$ & $-16,092$ & $-16,110$ & $-16,297$ & $-16,339$ & $-16,216$ \\
\hline B0N1 & 0 & 0 & 0 & 0 & 0 & 0 \\
\hline B10N1 & $-7,941$ & $-7,929$ & $-7,981$ & $-8,177$ & $-8,264$ & $-8,384$ \\
\hline $\mathrm{B} 20 \mathrm{~N} 1$ & $-15,945$ & $-15,896$ & $-15,846$ & $-15,700$ & $-15,731$ & $-15,828$ \\
\hline B0N2 & 0 & 0 & 0 & 0 & 0 & 0 \\
\hline $\mathrm{B} 10 \mathrm{~N} 2$ & $-7,837$ & $-7,702$ & $-7,707$ & $-7,938$ & $-7,997$ & $-7,727$ \\
\hline B20N2 & $-15,878$ & $-15,669$ & $-15,575$ & $-15,722$ & $-15,678$ & $-14,963$ \\
\hline
\end{tabular}

Note: See Table 2 
and hazardous substances) had positive effects on the soil properties and the reduction of greenhouse gas emissions. The results on the crop yields during 2014-2018 were already published as well (Aydin et al. 2020; Horák et al. 2020a) and the yields for the following years (from 2019 upwards) will be published in the near future.

Data for the calculation of the biochar application economy is shown in Table 1 (cost of biochar, cost of biochar application, and prices for commodities in the respective year). Currently, there are also biochars available at lower prices and the development in a biochar price reduction is making a rapid progress. Profit margin varied (Table 2) and depended on the amount of crop yield and the cost of management practices in the respective year. When the income was cumulatively totalled for individual treatments for the whole reporting period, the highest overall profit was observed in treatments with higher biochar and N-fertilisation rates (Table 2). When the income generated by the crop during each year was deducted from the initial amount, in case of biochar's rather high costs (biochar purchase and application costs at the beginning of the experiment in 2014), we noticed a high cumulative money loss for the reporting period. It is evident that both the application of biochar and its application in combination with $\mathrm{N}$-fertilisation in the field conditions at current operational prices of commodities in individual years and high input costs were unprofitable. We would like to emphasize that in this case, only the economic point of view of standard agronomic practice was considered. However, biochar application may be appealing to farmers in the long-term, especially if the other benefits (improvement of soil properties, mitigation of climate change, reduction, and usability of bio-waste etc.) will be accounted for. As stated by El-Naggar et al. (2019) investment in biochar application into the soil is a long-term issue that may discourage farmers from using it. However, its beneficial effects on the soil continue from several years up to decades, which might be appealing for farmers in the next period when compared to the application cost only (for example, compost or $\mathrm{N}$-fertiliser is applied several times over the same time period).

In our case, the price of 1 tonne of biochar was extremely high (producer from Austria, certified biochar), given the economic contribution to the standard production of market crops (an increase of crop yields in biochar treatments in comparison to control) under the field conditions. In general, economic efficiency is largely affected by the amount of applied biochar in optimal dosage. Low or too high biochar rates are not justified as they did not result insignificant effects on the soil properties and crop yields as reported by Chan et al. (2007). In our case, we applied doses of 10 and 20 t/ha in order to investigate the changes in soil properties as well as crop yields (Horák et al. 2020b; Horák et al. 2020a), and we found that the higher application rate significantly increased input costs (Table 1) and significantly influenced the production loss (Table 3 ). From the agronomic point of view, it is clear, that at such high input costs, soil additives such as biochar will not be attractive in standard cultivation practices used by farmers. Investments in biochar, which could provide an increase in production, may be profitable for farmers engaged in special crop production (There is a greater likelihood of increasing their production through soil management such as, the management of soil moisture and temperature). Special crop production has higher realisation costs of the crop yields and if higher production is achieved because of added biochar, the return of initial biochar investments could be eliminated in a shorter period - if we only look at it through the perspective of an ordinary farmer.

Of course, in our case, as well as in standard agronomic practice, the economic effect of biochar should also be assessed through the economic value of the improved soil properties (Verheijen et al. 2009). In other words, it should be considered to what extent the economic value (money) of the soil increases with improved soil properties. For example, when $\mathrm{C}$ content, nutrient content has increased, soil physics and sorption have improved, because of biochar application into the soil. Of course, there are also other matters to consider. For example, (and perhaps the most important issue in the case of the Slovak Republic), a substantial part of the agricultural land fund is rented to farmers by owners of the soil, and land lease contracts are signed mostly for 10 -year periods. Since the soil is not their property, 
farmers are not necessarily interested in investing a considerable amount of money for biochar in the soil unless they are convinced that such investments will be returned in a short time period through higher crop yields which can then be sold on the market. If farmers could work (or were working) on their own soil, they would probably be less resistant to higher investments in the soil where the investments are generally returned after a longer period of time.

\section{CONCLUSIONS}

As short-term biochar application is currently resulting in net loss, the focus should be on:

Economically efficient and profitable production of biochar, which would significantly reduce its final sale price resulting in lower biochar purchase costs. It is expected that such a reduction in the cost of biochar might make it an appealing product for farmers.

Encouraging farmers to see production not only through the profits generated by the crop yields. By highlighting that when biochar is applied to the soil, it contributes to the protection of the environment, health-friendly production and, last but not least, the improvement of the soils. Education on the importance of soil quality for sustainable management is crucial.

Open discussions with policy makers for possible subsidies of biochar substrates application into the soil. Considering the environmental profits of biochar usage, subsidies should be provided to farmers on the national level to offset the cost of biochar adoption.

Acknowledgements: The authors would like to very much thank Danny Angus (Belfast, Northern Ireland) for improving the English text and also the editor and the reviewers for constructive comments. This publication is the result of the project implementation: "Scientific support of climate change adaptation in agriculture and mitigation of soil degradation" (ITMS2014+ 313011W580) supported by the Integrated Infrastructure Operational Programme funded by the ERDF.

\section{REFERENCES}

AYDIN, E. - ŠIMANSKÝ, V. - HORÁK, J. - IGAZ, D. 2020. Potential of biochar to alternate soil properties and crop yields 3 and 4 years after the application. In Agronomy, vol. 10, pp. 889. DOI: 10.3390/agronomy10060889.

BARROW, C.J. 2012. Biochar: Potential for countering land degradation and for improving agriculture. In Applied Geography, vol. 34, pp. 21-28. DOI: 10.1016/j.apgeog.2011.09.008.

EL-NAGGAR, A. - LEE, S.S. - RINKELEBE, J. - FAROOQ, M. - SONG, H. - SARMAH, A.K. - ZIMMERMAN, A.R. - AHMAD, M. - SHAHEEN, S.M. - OK, Y.S. 2019. Biochar application to low fertility soils: A review of current status, and future prospects. In Geoderma, vol. 337, pp. 536-554. DOI: 10.1016/j.geoderma.2018.09.034.

HAN, L. - SUN, K. - YANG, Y. - XIA, X. - LI, F. - YANG, Z. - XING, B. 2020. Biochar's stability and effect on the content, composition and turnover of soil organic carbon. In Geoderma, vol. 364, 114-184. DOI: 10.1016/j.geoderma.2020.114184.

HORÁK, J. - ŠIMANSKÝ, V. - AYDIN, E. 2020a. Benefits of biochar and its combination with nitrogen fertilization for soil quality and grain yields of barley, wheat and corn. In Journal of Elementology, vol. 25, no. 2, pp. 443-458. DOI: 10.5601/jelem.2019.24.3.1887.

HORÁK, J. - ŠIMANSKÝ, V. - IGAZ, D. - JURIGA, M. AYDIN, E. - LUKAC, M. 2020b. Biochar: An important component ameliorating the productivity of intensively used soils - review. In Polish Journal of Environmental Studies, vol. 29, no. 5, pp. 2995-3001. DOI: 10.15244/ pjoes/113128.

CHAN, K.Y. - VAN ZWIETEN, L. - MESZAROS, I. - DOWNIE, A. - JOSEPH, S. 2007. Agronomic values of green waste biochar as a soil amendment. In Australian Journal of Soil Research, vol. 45, no. 8, pp. 629-634. DOI: 10.1071/ SR07109.

JEFFERY, S. - VERHEIJEN, F.G.A. - VELDE, M. - BASTOS, A.C. 2011. A quantitative review of the effects of biochar application to soils on crop productivity using meta-analysis. In Agriculture, Ecosystems \& Environment, vol. 144, pp. 175 -187. DOI: 10.1016/j.agee.2011.08.015.

LEHMANN, J. - JOSEPH, S. 2015. Biochar for Environmental Managements, Science, technology and Implementation, 1st ed., London, New York: Routledge, pp. 928.

LONE, A.H. - NAJAR, G.R. - GANIE, M.A. - SOFI, J.A. ALI, T. 2015. Biochar for sustainable soil health: A review of prospects and concerns. In Pedosphere, vol. 25, no. 5, pp. 639-653. DOI: 10.1016/S1002-0160(15)30045-X.

RAKSHIT, A. - SARKAR, B. - ABHILASH, P.CH. 2019. Soil Amendments for Sustainability, Challenges and Perspectives, 1st ed., Boca Raton, FL: Taylor and Francis Group, pp. 403.

RIZHIYA, E.Y. - MUKHINA, I.M. - BALASHOV, E.V. ŠIMANSKÝ, V. - BUCHKINA, N.P. 2019. Effect of biochar on $\mathrm{N}_{2} \mathrm{O}$ emission, crop yield and properties of Stagnic Luvisol in a field experiment. In ZemdirbysteAgriculture, vol. 106, no. 4, pp. 297-306. DOI: 10.13080/ z-a.2019.106.038.

SHACKLEY, S. - RUYSSCHAERT, G. - ZWART, K. - GLASER, B. 2016. Biochar in European Soils and Agriculture, Science and Practice, 1st ed., London, New York: Routledge, pp. 301.

ŠIMANSKY, V. - HORÁK, J. - POLLÁKOVÁ, N. - JURIGA, M. - JONCZAK, J. 2019. Will the macro and micronutrient content in biochar show in the higher content of the individual parts of corn? In Journal of Elementology, vol. 24, no. 2, 
pp. 525-537. DOI: 10.5601/jelem.2018.23.2.1671.

TAMMEORG, P. - BASTOS, A.C. - JEFFERY, S. - REES, F. - KERN, J. - GRABER, E.R. - VENTURA, M. - KIBBLEWHITE, M. - AMARO, A. - BUDAI, A. - CORDOVIL, C.M.D.S. - DOMENE, X. - GARDI, C. - GASCÓ, G. - HORÁK, J. - KAMMANN, C. KONDRLOVÁ, E. - LAIRD, D. - LOUREIRO, S. MARTINS, M.A.S. - PANZACCHI, P. - PRASAD, M. - PRODANA, M. - PUGA, A.P. - RUYSSCHAERT, G. - SAS-PASZT, L. - SILVA, F.C. - TEIXEIRA, W.G. - TONON, G. - VEDOVE, G.D. - ZAVALLONI, C. GLASER, B. - VERHEIJEN, F.G.A. 2017. Biochars in soils: Towards the required level of scientific understanding. In Journal of Environmental Engineering and Landscape Management, vol. 25, no. 2, pp. 192-207. DOI: 10.3846/16486897.2016.1239582.

VERHEIJEN, F.G.A. - JEFFERY, S. - BASTOS, A.C. - VAN DER VELDE, M. - DIAFAS, I. 2009. Biochar Application to Soils - A Critical Scientific Review of Effects on Soil Properties, Processes and Functions, 1st ed., Luxembourg: Office for the Official Publications of the European Communities, pp. 149. DOI: 10.2788/472.

Received: September 10, 2020 Accepted: December 14, 2020 